\title{
СУЧАСНИЙ СТАН РОЗВИТКУ МІКРО ТА МАЛОГО АГРОБІЗНЕСУ В УКРАЇНI
}

Мета. Метою статті є розкриття особливостей функиіонування мікро та малих агропідприємств в Україні, виявлення негативних факторів впливу на результат діяльності таких підприємств і формування напрямів розвитку малого агробізнесу.

Методологія / методика / підхід. Методологічною основою дослідження є системний підхід до вивчення економічних явищ. Серед спеціальних методів використано абстрактнологічний метод при виділенні особливостей функціонування малих підприємств України та формуванні висновків і рекомендацій; економіко-статистичний - при виявленні тенденцій $i$ закономірностей розвитку мікро та малих підприємств; метод порівняння - при дослідженні динаміки окремих показників і графічний - при аналізі статистичних даних.

Результати. Розглянуто проблеми сучасного стану та динаміки розвитку мікро та малих підприємств аграрного спрямування. Наведено результати аналізу функиіонування таких підприємств та їх значення в агробізнесі України. Виділено негативні фактори впливу на результат діяльності малих підприємств $i$ необхідність державної підтримки. Обгрунтовано необхідність інновачійного розвитку мікро та малого агробізнесу. Досліджено основні напрями становлення та розвитку малого агробізнесу на перспективу.

оригінальність / наукова новизна. Надано авторське трактування терміну «агробізнес»; дістали дальшого дослідження особливості функиіонування таких підприємств, визначення їх основних складових частин; визначено місие таких підприємств у сучасному агробізнесі та сформовано основні напрями розвитку.

Практична цінність / значущість. Запропоновано конкретні заходи щодо напрямів розвитку малого агробізнесу України. Серед основних напрямів слід виділити вдосконалення податкової системи та доступність кредитування агробізнесу.

Ключові слова: агробізнес, мікро підприємства, малі підприємства, операчійна діяльність, рентабельність, інновачійний розвиток, кредитування.

\section{Alisa Shevchenko, Olga Petrenko \\ Odessa State Agrarian University Ukraine}

\section{CURRENT STATE OF MICRO AND SMALL AGRIBUSINESS IN UKRAINE}

Purpose. The purpose of the article is to reveal the peculiarities of functioning of micro and small agribusinesses in Ukraine, to identify the negative factors influencing the result of such enterprises and to formulate directions for the development of small agribusiness.

Methodology / approach. The methodological basis of the research is a systematic approach 


\section{Agricultural and Resource Economics}

www.are-journal.com

to the study of economic phenomena. Among the special methods, the abstract-logical method was used to highlight the peculiarities of functioning of small enterprises of Ukraine and to formulate conclusions and recommendations; economic-and-statistical, in identifying trends and patterns of development of micro and small enterprises; method of comparison, in the study of the dynamics of individual indicators and graphical, in the analysis and presentation of statistical data.

Results. The problems of the current state and dynamics of development of micro and small agricultural enterprises are considered. The results of the analysis of functioning of such enterprises and their importance in agribusiness of Ukraine are presented. The negative factors influencing the result of small business activity and the need for state support are highlighted. The necessity of innovative development of micro and small agribusiness is substantiated. The basic directions of formation and development of small agribusiness for the future are investigated.

Originality / scientific novelty. Author's interpretation of the term "agribusiness» is provided; the peculiarities of the functioning of micro and small enterprises in Ukraine, determination of their main components received further study; the place of such enterprises in the modern agribusiness is determined and the main directions of development are formed.

Practical value / implications. The concrete measures on directions of small agribusiness development in Ukraine are offered. Improvement of the tax system and availability of agribusiness lending are among the main ones.

Key words: agribusiness, micro enterprises, small enterprises, operating activities, profitability, innovative development, lending.

Постановка проблеми. У теперішніх умовах розвиток малого агробізнесу в Україні має вирішальне значення. Зокрема, це пов'язано із вступом України до СОТ, що створило для аграріїв сприятливі фактори для їх функціонування. Звернемо увагу, що розвиток мікро та малого агробізнесу є важливим напрямом вирішення низки проблем, що мають місце в сучасній економіці України. Так, у сучасних умовах децентралізації можливо наповнити за рахунок мікро та малого бізнесу місцеві бюджети селищних рад, а також підкріплювати здорову конкуренцію на ринку аграрної продукції, сприяти розвитку сільських територій (для багатьох селян зайняття агробізнесом на власних та орендованих земельних ділянках є єдиною можливістю отримання доходу та власне «виживання»). Тому важливого значення набуває створення сприятливих умов для подальшого розвитку мікро та малих підприємств.

Аналіз останніх досліджень i публікацій. Питанням розвитку та особливостям функціонування мікро та малого агробізнесу присвячували свої дослідження такі вітчизняні науковці, як: О. Апостолюк [1], А. Дерев'янко [2], О. Сфремова [3], С. Іваницька, Ю. Троян [4], К. Мазур, Л. Сімоник [5], Г. Мостовий [6], Ю. Сівіцька [7], О. Фінагіна [8], Д. Шемякин [9] та інші. Питання сталого розвитку малих аграрних підприємств (фермерських i сімейних господарств) у своїх працях висвітлювали зарубіжні вчені: S. Davidova, M. Gorton, T. Ratinger, K. Zawalinska, B. Iraizoz [10], L. Ling [11], T. Poufinas, G. Galanos, P. Papadimitriou [12], J. Savickiene, A. Miceikiene [13], S. Sousa, E. Aspinwall, A. Rodrigues [14], J. Spicka, T. Hlavsa, K. Soukupova, M. Stolbova [15], G. Ruchkina, M. Melnichuk, S. Frumina, G. Mentel [16], O. Teletov, V. Grigorenko [17]; в частині інноваційного розвитку таких підприємств - N. Jankelova, K. Remenova, Z. Skorkova, I. Nemethova [18]. 


\section{Agricultural and Resource Economics}

www.are-journal.com

Проте, сучасний стан розвитку таких підприємств, несприятливі умови функціонування та недосконалий механізм державної підтримки, потребують подальшого дослідження цього питання.

Метою статті є розкриття особливостей функціонування мікро та малих агропідприємств в Україні, виявлення негативних факторів впливу на результат діяльності таких підприємств i формування напрямів розвитку малого агробізнесу.

Виклад основного матеріалу дослідження. Розглядаючи термін «агробізнес», слід звернути увагу, що єдиної установленої думки серед науковців на трактування цієї категорії немає, що потребує нашої уваги в цьому напрямі досліджень. У науковій літературі широко застосовуються два поняття: «підприємництво» та «бізнес». Ми погоджуємось із рядом науковців, що вважають категорію «бізнес» ширшою за «підприємництво», оскільки бізнес включає коло економічних зв'язків і зі споживачами, і працівниками, і 3 владою. Учений Г. Мостовий формулює агробізнес, як: «форму господарювання в аграрному секторі або як комплекс видів підприємницької діяльності, пов'язаних із виробництвом сільськогосподарської продукції, іiі зберіганням, транспортуванням, переробкою та доведенням до споживача, а також із виробництвом засобів виробництва для сільського господарства» [6].

Слід зауважити, що інші дослідники більш широко пояснюють цю категорію. Агробізнес розглядається у тісному взаємозв'язку із населенням. На нашу думку, агробізнес - це система відносин між усіма елементами інфраструктури аграрного ринку, що пов'язані із виробництвом аграрної продукції та супутніх видів діяльності й передбачає отримання прибутку на основі задоволення потреб споживачів.

Звернемо увагу, що в Україні є поділ підприємств на типи згідно зі статтею 55 Господарського кодексу України [19] (у дужках наведено граничні критеріі): суб'єкти мікропідприємництва (до 10 осіб працівників, річний дохід не перевищує суму, еквівалентну 2 млн євро), суб'єкти малого підприємництва (до 50 осіб працівників, річний дохід не перевищує суму, еквівалентну 10 млн євро), середнього підприємництва (до 250 осіб працівників, річний дохід не перевищує суму, еквівалентну 50 млн євро) та великого підприємництва (більше 250 осіб працівників, річний дохід перевищує суму, еквівалентну 50 млн євро). Для розрахунку показників у євро застосовують офіційний курс гривні, що $\epsilon$ середнім за період, який розраховують на основі курсів Національного банку України (НБУ), що були протягом відповідного періоду.

Можливість деяких організаційно-правових форм мікро та малого агробізнесу, згідно із чинним законодавством України, наймати робочу силу зменшить проблему безробіття на селі. Вагомий внесок $є$ також мікро та малого агробізнесу в нарощуванні обсягів валового внутрішнього продукту в Україні. Так, Д. Шемякин відмічає: «малий і середній бізнес в Україні приносить $55 \%$ валового внутрішнього продукту в економіку країни (у т. ч. мікро та малий бізнес $16 \%$ ), а в Свропі - у два рази більше й ефективність їх функціонування у 


\section{Agricultural and Resource Economics \\ www.are-journal.com}

10 разів є вищою, ніж в Україні [9].

Як зазначає О.В. Фінагіна, «малий та середній агробізнес через його значну численність і розповсюдженість на території країни $\epsilon$ потужним каталізатором і стимулятором ділової активності, зумовлює об'єднання всіх учасників економічних відносин у країні. Його підтримка та ефективний розвиток .... створює підгрунтя для появи й функціонування інституційного середовища» [8].

Для більш повного розуміння напрямів дальшого розвитку малих аграрних підприємств, нами згруповано особливості функціонування таких підприємств (рис. 1). Необхідно відмітити, що малим аграрним підприємствам в Україні дуже важко конкурувати із великими підприємствами, які мають значні переваги у своїй діяльності.

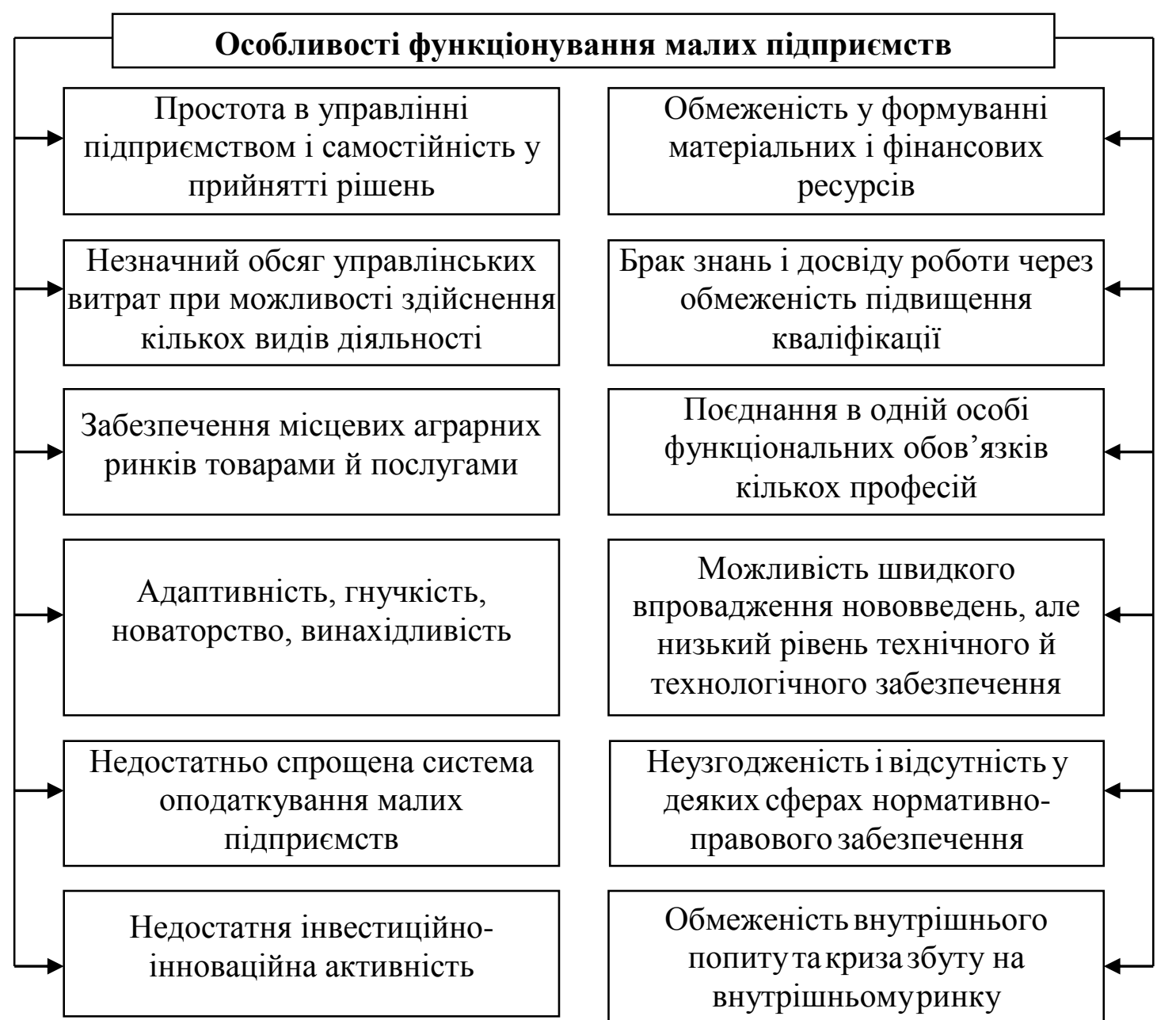

Рис. 1. Особливості функціонування малих агропідприємств в Україні Джерело: узагальнили автори.

Тому аграріям мікро та малого бізнесу доводиться займатись винахідництвом, творчим пошуком нових ідей щодо втримання наявних ринкових позицій, а також майбутнього процвітання. Але, на нашу думку, у суб'єктів мікро та малого агробізнесу є великі перспективи, спрямовані на інноваційну складову частину розвитку.

Для більшого розуміння напрямів розвитку агропідприємств мікро та 


\section{Agricultural and Resource Economics \\ www.are-journal.com}

малого бізнесу, розглянемо сучасний стан цих підприємств, зокрема їх наявність і динаміку в державі (рис. 2, 3). Як видно з рис. 2, станом на 2018 рік в Україні в сільському, лісовому та рибному господарстві зареєстровано 68492 мікро суб'єктів господарювання, при цьому у 2018 році проти 2010 року їх кількість зменшилася на $5 \%$.

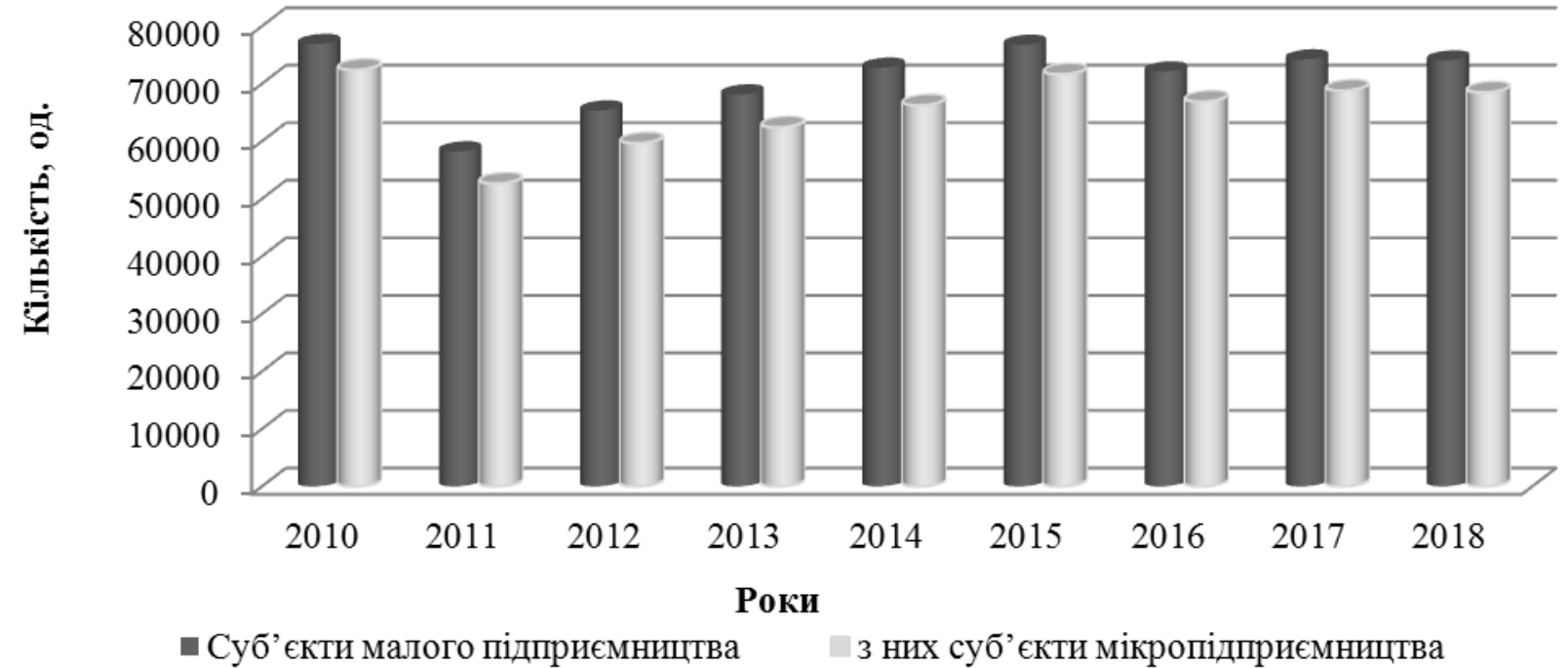

Рис. 2. Кількість малих та мікро суб'сктів господарювання в сільському, лісовому та рибному господарстві України, од.

Джерело: побудовано авторами за даними Державної служби статистики України [20].

Це відбулося за рахунок зростання частки великих суб’єктів в Україні на $77 \%$ i також зменшення кількості середніх за розмірами суб'єктів господарювання на $35 \%$. Протягом 2011-2015 років кількість мікро суб'єктів господарювання зростала, а потім зменшилася. Питому вагу мікропідприємств аграрного сектора представлено на рис. 3.

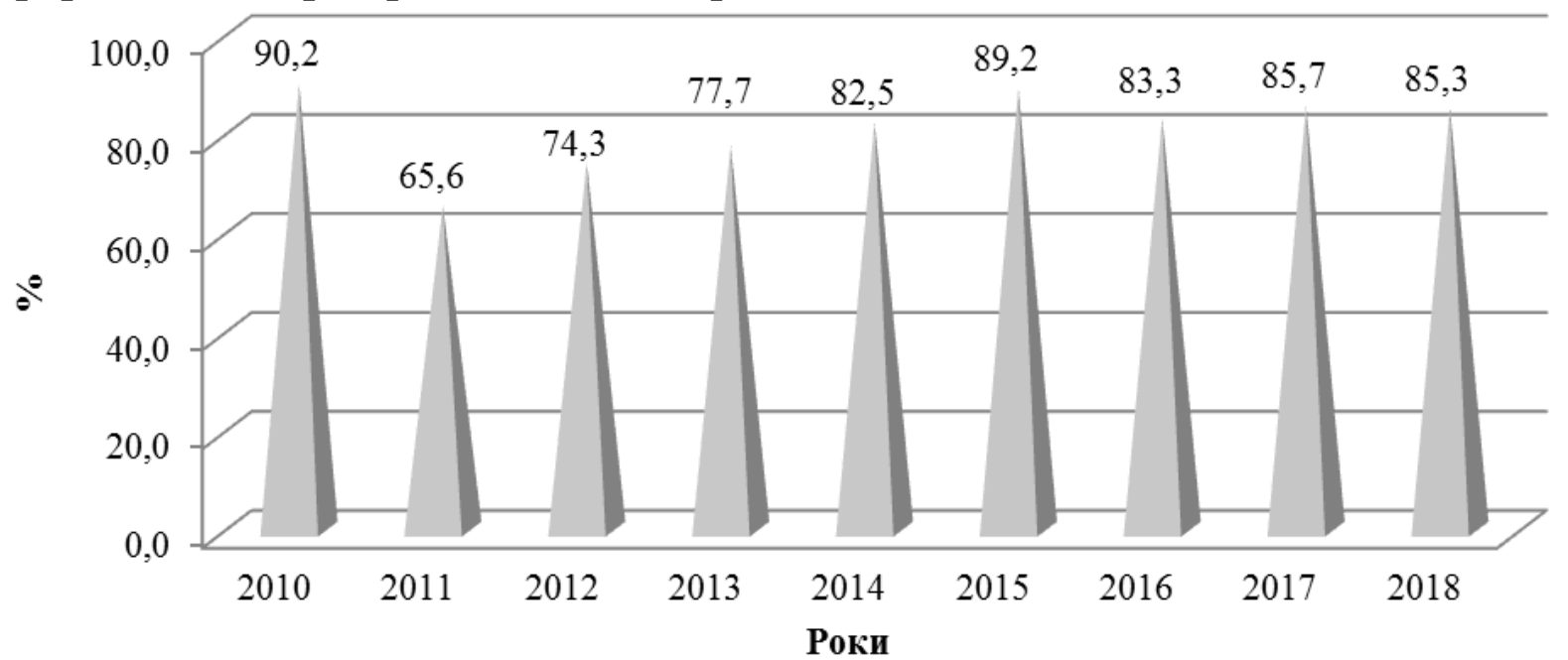

Рис. 3. Частка мікропідприємств у загальній кількості суб'єктів господарювання в сільському, лісовому та рибному господарстві України, \%

Джерело: побудовано авторами за даними Державної служби статистики України [20].

Як видно з даних рис. 3, питома вага мікро суб'єктів господарювання зазначеної галузі в загальній кількості суб'єктів господарювання є досить 


\section{Agricultural and Resource Economics \\ www.are-journal.com}

високою та становила у 2018 році $85 \%$. Це підтверджує високий рівень концентрації саме цього типу за розмірами суб'єктів господарювання в Україні.

Понад дві третини власників малого та мікро бізнесу вважають, що економічні фактори є причиною припинення діяльності, а одна третя відмічає основною причиною закриття бізнесу відсутність прибутку. Ми вважаємо, що такі зміни пов'язані із присутністю конкурентної боротьби в підприємницькій діяльності в Україні, що є природним фактором «виживання» найсильніших виробників. Варто зауважити також, що у переважній кількості малих суб'єктів господарювання, які функціонують у більш-менш стабільному середовищі, відсутня мотивація для розширення бізнесу і вони господарюють у наявних межах до тих пір, поки виникає питання вибору - розширюватися, вибираючи нову стратегію функціонування, чи згортати обороти у зв'язку із тиском конкурентів та загрозою втратити частку ринку.

Переважна кількість керівників довіряють тільки самим собі, а зростання масштабів діяльності потребує додаткового залучення управлінського персоналу, що підвищує ризикованість у дальшій діяльності. Але ефективна система менеджменту в суб'єктів господарювання є основою їх прибутковості незалежно від розміру бізнесу та форм діяльності. Проте «стереотип сам керівник у бізнесі» майже неможливо перебудувати в країнах, які тривалий час перебували під впливом адміністративно-командної економіки.

Звичайно, мікро суб’єкти господарювання не можуть конкурувати із великим бізнесом в Україні, але, як видно 3 рис. 4, у малих за розмірами суб'єктах господарювання зосереджено у 2018 році 43 \% зайнятого населення в сільському, лісовому та рибному господарстві в тому числі в мікробізнесі $23 \%$ і в порівнянні із 2010 роком частка відповідно зросла на $11 \%$ та 5,3\%.

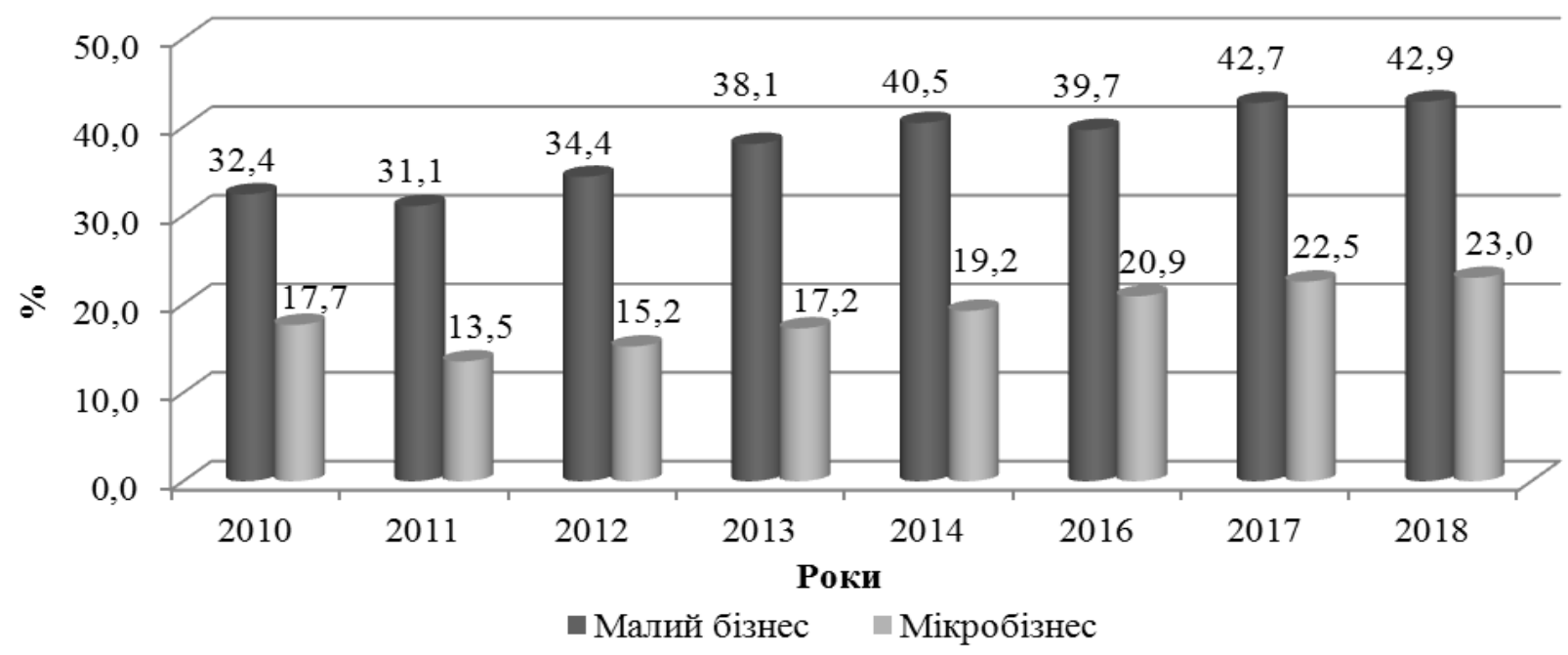

Рис. 4. Частка малого та мікро бізнесу в загальній кількості зайнятих працівників суб'сктів господарювання в сільському, лісовому та рибному господарстві України, \%

Джерело: побудовано авторами за даними Державної служби статистики України [20].

Наступним критерієм функціонування підприємств цієї категорії $\epsilon$ вироблена продукція такими суб'єктами, результати якої наведено на рис. 5. 


\section{Agricultural and Resource Economics \\ www.are-journal.com}

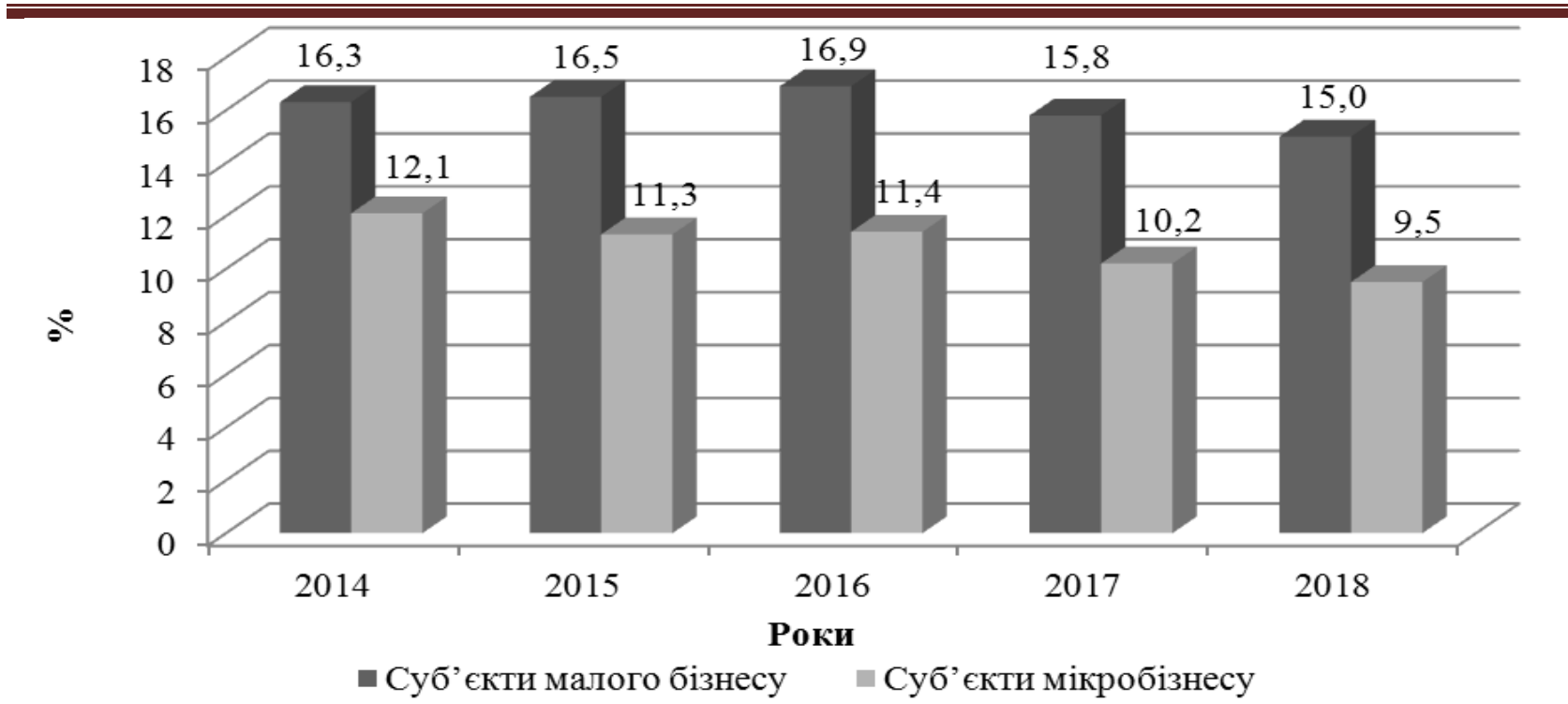

Рис. 5. Частка виробленої продукції (товарів, послуг) малого та мікро агробізнесу в загальній кількості продукції (товарів, послуг) малого та середнього бізнесу в Україні, \%

Джерело: побудовано авторами за даними Державної служби статистики України [20].

Слід відмітити негативну тенденцію частки виробленої продукції (товарів, послуг) малого та мікро агробізнесу в загальній кількості продукції (товарів, послуг) малого та середнього бізнесу в Україні у 2018 році в порівнянні із 2014 роком - вона зменшилася відповідно на 1,3 \% та 2,6 \%. Це пов'язано як із скороченням кількості суб'єктів малого бізнесу, так і з недоліками в організації виробництва продукції (товарів, послуг). Якщо розглядати галузеву спрямованість мікропідприємств в аграрній сфері в Україні, то переважають підприємства, що мають зерно-технічне спрямування. Така тенденція пояснює збільшення виробництва зернових, зернобобових і насіння олійних культур суб'єктами мікро агробізнесу в Україні. Так, у 2018 році проти 2014 року виробництво зазначеної продукції зросло більш, ніж у два рази (рис. 6).

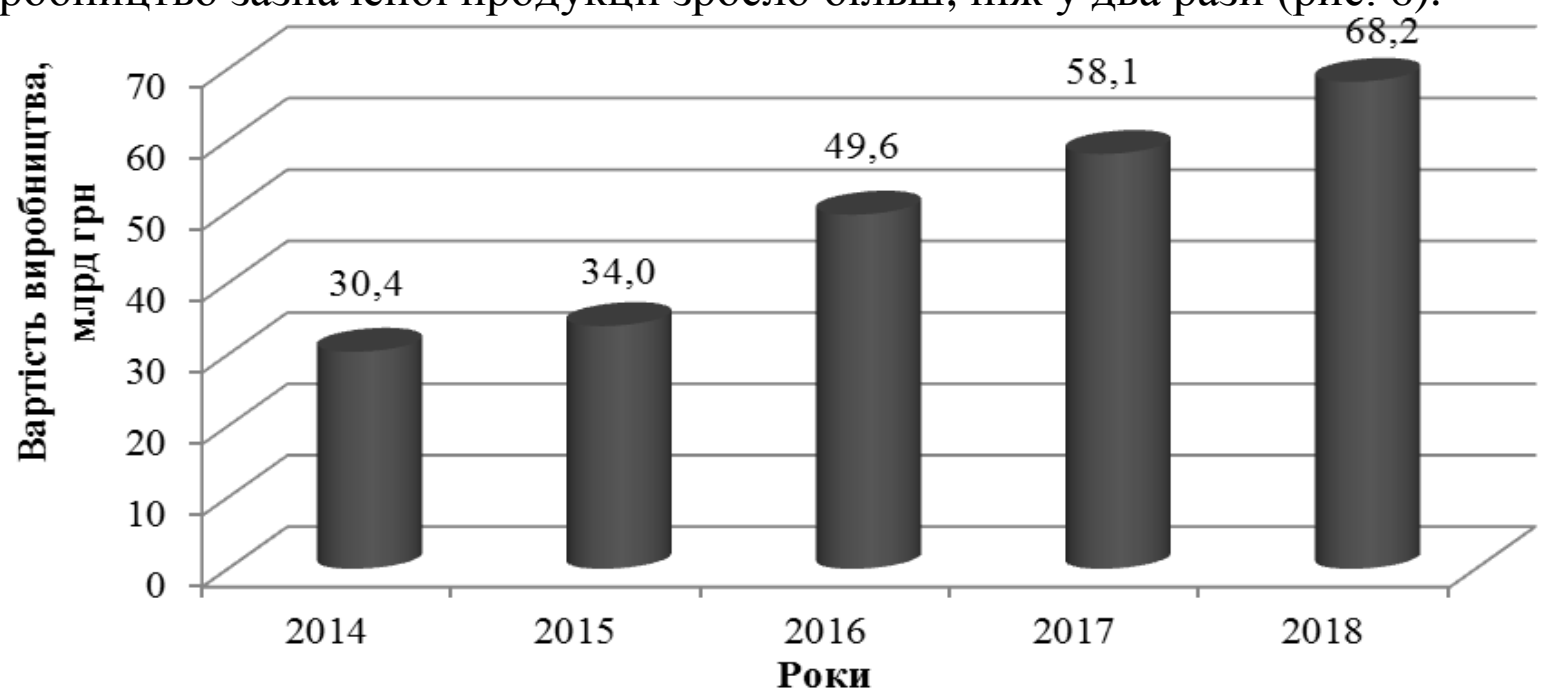

Рис. 6. Вартість виробництва зернових, зернобобових і насіння олійних культур суб'сктами мікро агробізнесу в Україні, млрд грн Джерело: побудовано авторами за даними Державної служби статистики України [20]. 


\section{Agricultural and Resource Economics \\ www.are-journal.com}

Основним фінансовим показником діяльності мікро підприємств виступає прибуток. У 2018 році проти 2010 року кількість прибуткових мікропідприємств в Україні збільшилася на 23,5\% (рис. 7), що є позитивним зрушенням. Але поряд із тим у 2018 році $14 \%$ мікропідприємств отримали чистий збиток, у той час як серед великих підприємств не було жодного збиткового, а поміж середніх за розміром підприємств тільки 11,6\% підприємств отримали збитки. Це спонукає на думку про необхідність державного регулювання діяльності таких підприємств.

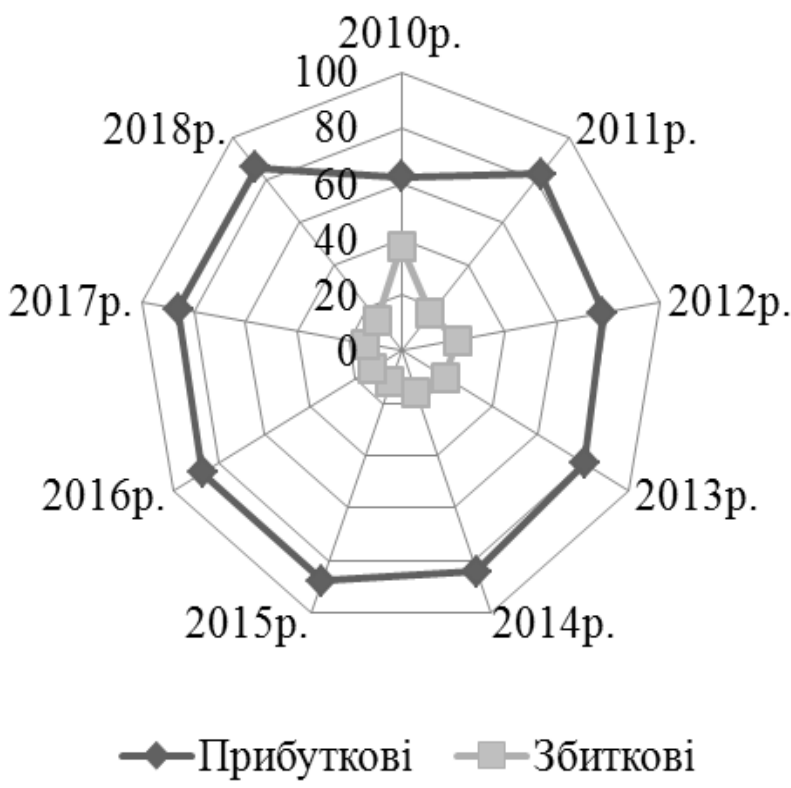

Рис. 7. Частка мікропідприємств, що отримали чистий прибуток (збиток) в Україні, \%

Джерело: побудовано авторами за даними Державної служби статистики України [20].

Тому необхідно розглянути основні негативні фактори впливу на результат діяльності малих підприємств в Україні. Відмітимо, що в Україні самі підприємці, у зв'язку із негативними соціально-економічними факторами, не очікують отримання прибутків (рис. 8) через ряд несприятливих чинників, головним із яких $є$ недосконала податкова система. Вагомим стримувальним чинником є корупційна система, яка блокує розвиток конкурентоспроможного агробізнесу в Україні. Так, за результатами дослідження Transparency International, Україна отримує 30-32 бали із 100 можливих у рейтингу сприйняття корупції (РСК). Рейтинг формується як результат опитування експертів і представників бізнесу, що здійснюють міжнародні організації.

Але не це виступає чинником недовіри бізнесменів, а дуже повільна динаміка зміни показників позиції, що свідчить про те, що державні органи не використовують узагалі або використовують неефективну політику в боротьбі 3 корупцією. Також важливим стримувальним чинником розвитку малого бізнесу $€$ обмеженість у використанні кредитних коштів. 


\section{Agricultural and Resource Economics \\ www.are-journal.com}

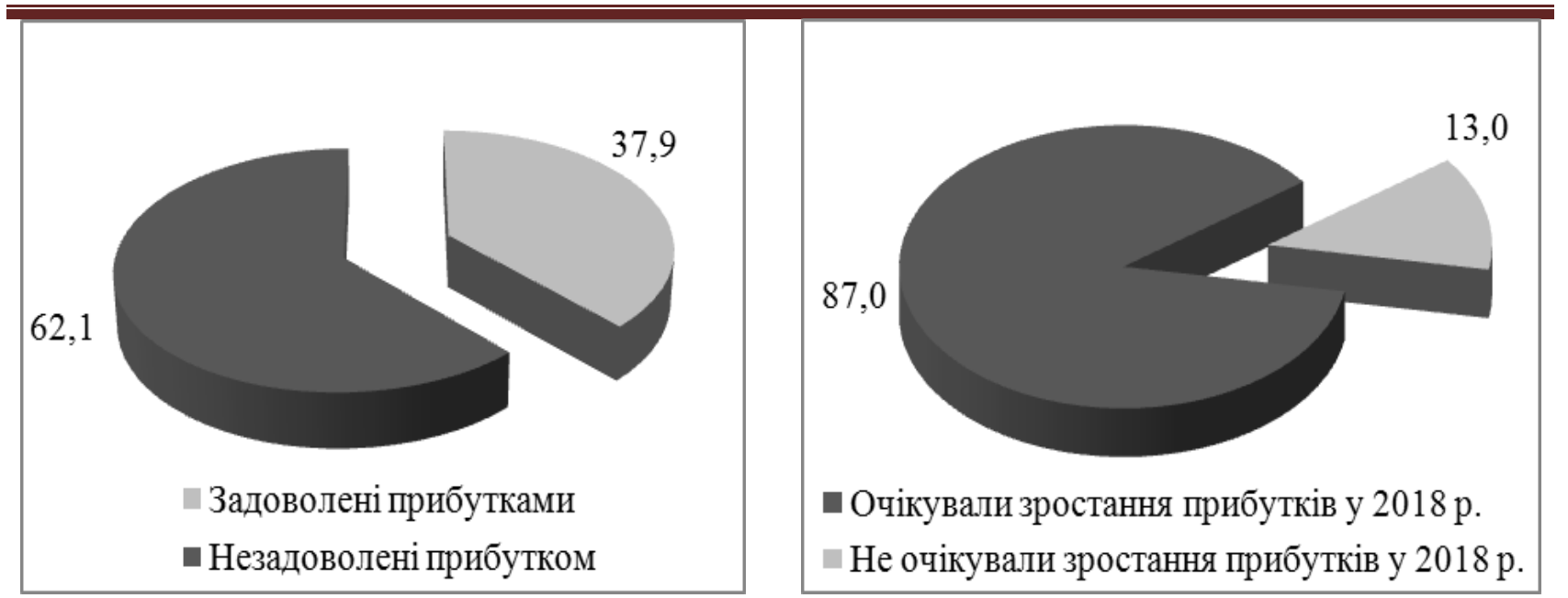

Рис. 8. Показники оцінки ставлення підприсмців малого бізнесу до результатів власної діяльності, \%

Джерело: побудовано на основі даних [2].

За результатами досліджень групи ЕВА визначено, що основна кількість малих підприємств не мають можливості отримати кредитні кошти в необхідному обсязі для розширення власної справи, оскільки плата за кредитами малого бізнесу є суттєво вищою, ніж ціна кредитних ресурсів, які пропонуються великому бізнесу (рис. 9).

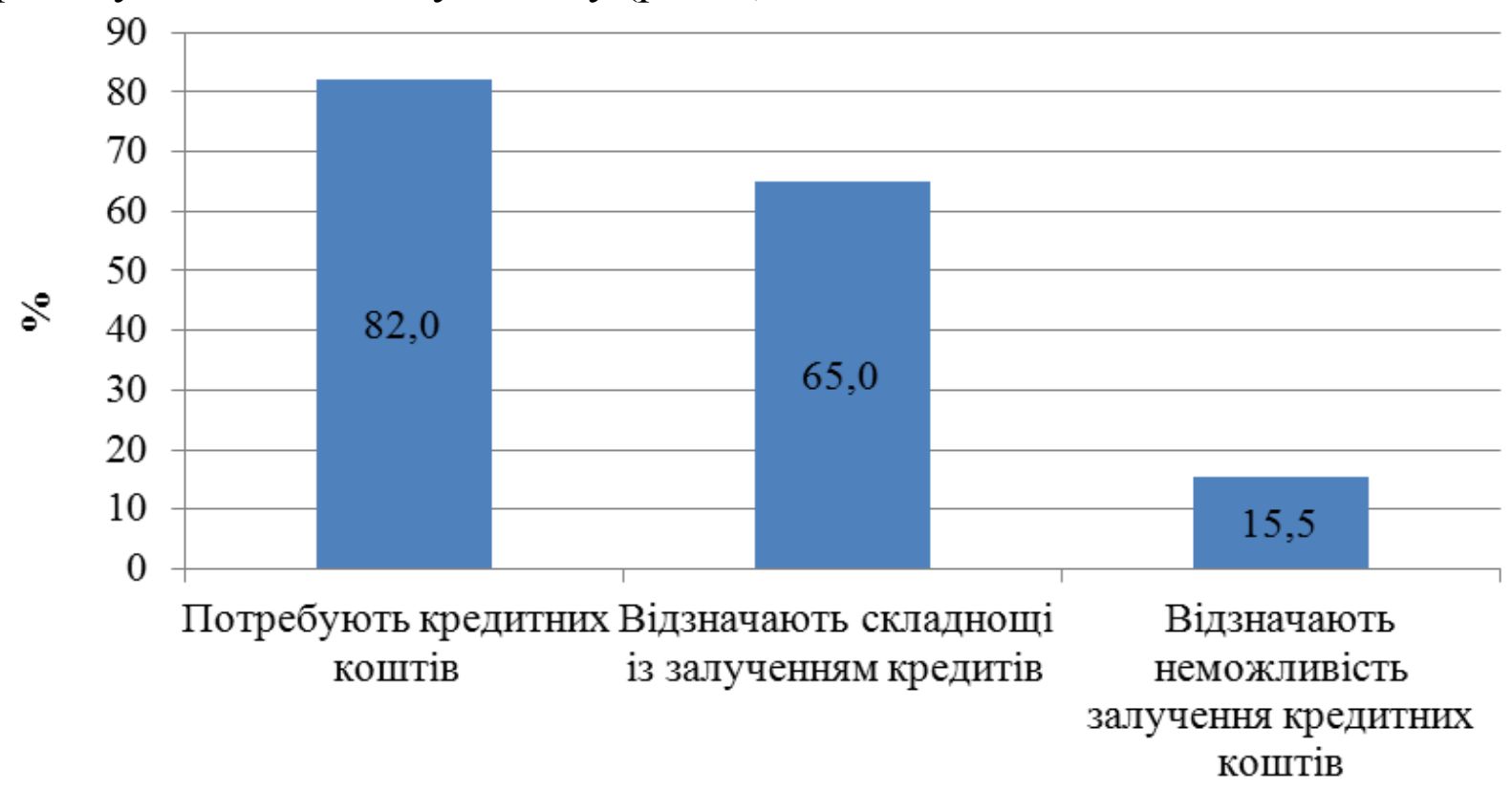

Рис. 9. Доступність кредитування для малого бізнесу в Україні, 2018 р. Джерело: побудовано на основі даних [2].

3 метою аналізу сприятливості бізнес-середовища будь-якої країни застосовується рейтинг, розроблений Світовим банком під назвою «Doing Business». Він дозволяе визначити як упроваджуються будь-які зміни в законодавстві з метою покращення бізнесу в країні. В оцінюванні беруть участь 190 країн [4].

Критерії рейтингу включають ряд вагомих складників. Україна отримала низькі результати в зазначеному рейтингу «Doing business» (рис. 10), із чого 


\section{Agricultural and Resource Economics \\ www.are-journal.com}

можна зробити висновок про несприятливий клімат бізнес-середовища для розвитку малих і середніх підприємств.

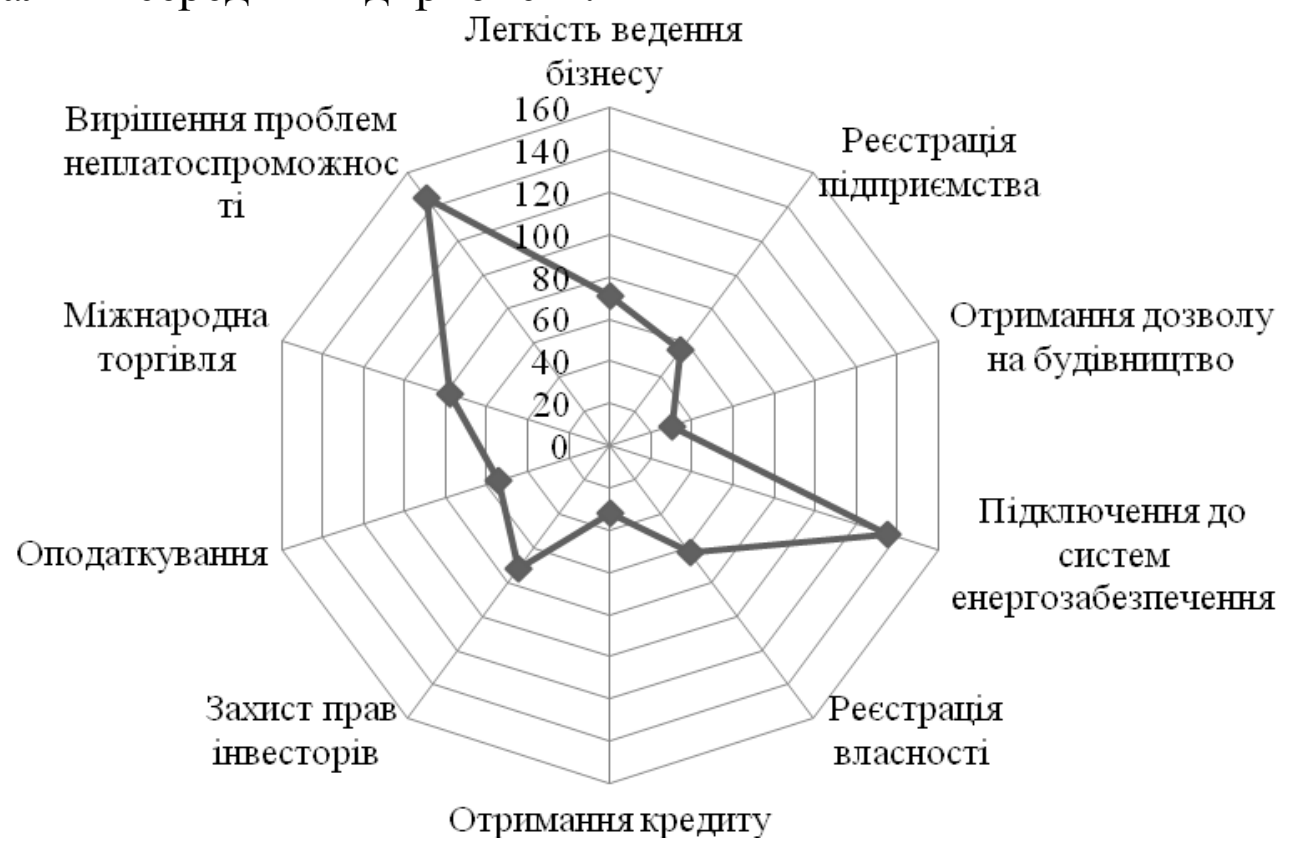

Рис. 10. Показники України в рейтингу «Ведення бізнесу - 2018»

Джерело: побудовано на основі офіційних даних групи Світового банку [21].

Ми вважаємо, що малий бізнес в Україні перебуває на стадії стагнації, але можливостей для виведення його з кризового стану в національній економіці $\epsilon$ багато й особливої уваги заслуговує розвиток на інноваційній основі. На рис. 11 представлені обставини інноваційного розвитку мікро та малого агробізнесу.

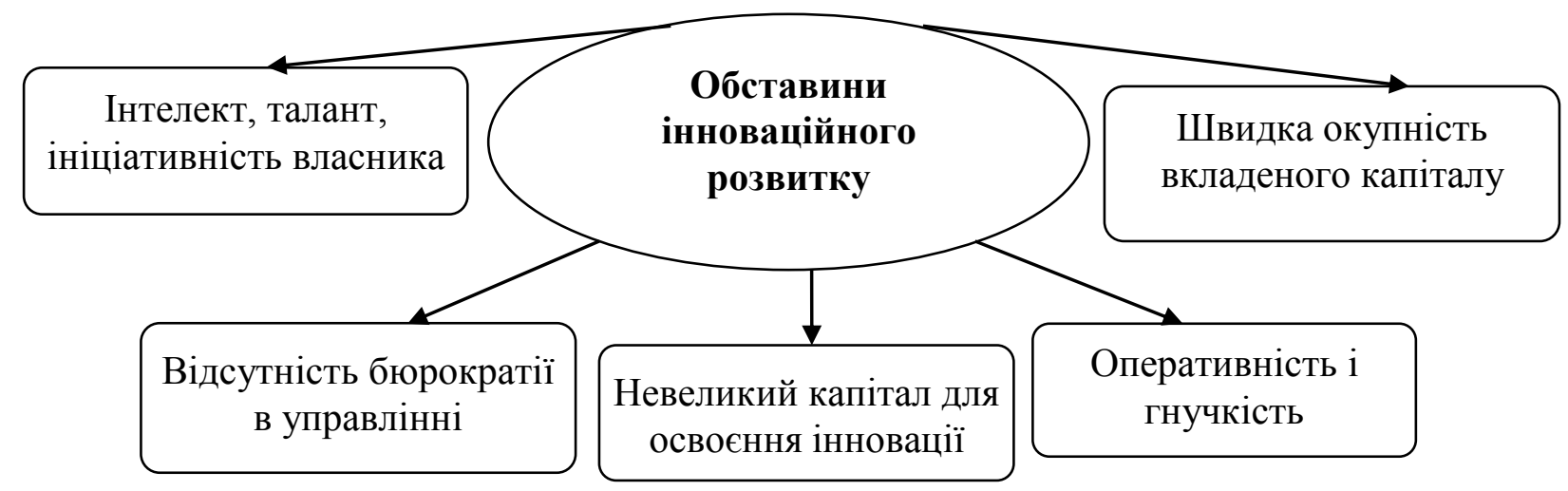

\section{Рис. 11. Обставини інноваційного розвитку мікро і малого агробізнесу в Україні}

Джерело: узагальнили автори на основі аналізу літератури.

Але розвиток малого агробізнесу можливий в Україні тільки за кейнсіанської моделі ставлення держави до бізнесу. Також ми вважаємо, що необхідно вивчити зарубіжний досвід розвитку малого агробізнесу й відпрацювання на цій основі виважені напрями становлення й розвитку на перспективу. На рис. 12 представлено ймовірні напрями розвитку малого агробізнесу в Україні на перспективу. 


\section{Agricultural and Resource Economics \\ www.are-journal.com}

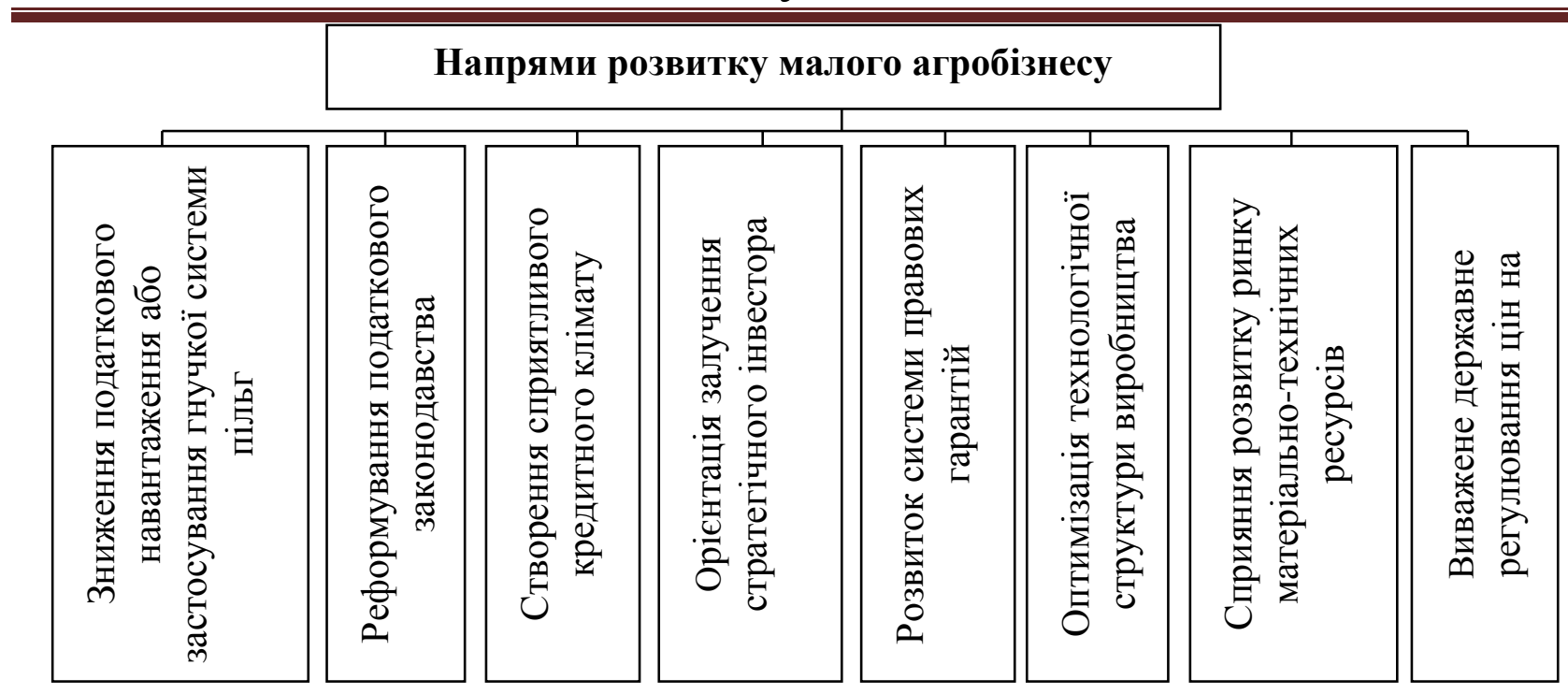

Рис. 12. Напрями розвитку мікро та малого агробізнесу в Україні

Джерело: узагальнили автори на основі аналізу літератури.

Висновки. На основі аналізу сучасного стану функціонування мікро та малих агропідприємств наведено оцінку розвитку таких підприємств. Виявлено, що в середньому за останні п’ять років у загальній кількості всієї виробленої продукції (товарів, послуг) агробізнесу 27,0 \% становила продукція саме малого та мікро агробізнесу. Це актуалізує значення малого агробізнесу в економіці країни, розвиток якого підвищує еластичність ведення бізнесу, сприяє розширенню ринку реалізації продукції, виявляє резерви використання виробничих ресурсів. Проте виявлено ряд негативних факторів, які перешкоджають реалізації завдань функціонування мікро та малого агробізнесу в Україні. Серед основних виділено несприятливий клімат бізнес-середовища для розвитку малих і середніх підприємств, а саме: недосконала податкова система, корупційна система, яка блокує розвиток конкурентоспроможного агробізнесу в Україні, недостатня можливість отримати кредитні кошти в необхідній кількості для розширення власної справи.

Отже, 3 метою покращення умов розвитку та функціонування малого агробізнесу в Україні нами сформовано основні напрями розвитку мікро та малих агропідприємств. Серед першочергових слід виділити інноваційний шлях розвитку, перебудову та реформування системи оподаткування малого бізнесу, надання консультацій і бізнес-тренінгів стосовно сучасних методик та викликів ведення агробізнесу по-новому, потребує корективів i система кредитування малого агробізнесу в Україні за спрощеною системою. Реалізація зазначених заходів дасть змогу малому агробізнесу нарощувати експортний потенціал, розширювати свої можливості й обсяг виробництва продукції. Саме удосконалення державної підтримки стосовно мікро та малого агробізнесу і $\epsilon$ перспективним напрямом дослідження.

\section{Список використаних джерел}

1. Апостолюк О. Ю. Державна фінансова політика підтримки розвитку малого підприємництва: автореф. дис. ... канд. екон. наук. Київ, 2017. 20 с. 


\section{Agricultural and Resource Economics}

www.are-journal.com

2. Дерев'янко А. Індекс настроїв малого бізнесу. URL: https://eba.com.ua/wp-content/uploads/2018/03/Indeks-nastroyiv-malogo-biznesu.

3. Єфремова О.С. Кредитування малого підприємництва в Україні. Економіка та держава. 2018. № 7. С. 82-85.

4. Іваницька С. Б., Троян Ю. Т. Перспективи розвитку малого та середнього підприємництва в Україні. Modern Economics. 2019. № 18. С. 49-54. https://doi.org/10.31521/modecon.V18(2019)-08.

5. Мазур К. В., Сімоник Л. С. Стан бізнес-середовища малих та середніх підприємств в Україні. Молодий вчений. 2018. № 5(57). С. 726-729.

6. Мостовий Г. І. Агробізнес: державне регулювання: монографія. Харків: Основа, 2002. 300 c.

7. Сівіцька Ю. О. Оцінка сільськогосподарського підприємства для інвестиційних цілей: методологічний аспект. Modern Economics. 2019. № 15. C. 175-182. https://doi.org/10.31521/modecon.V15(2019)-25.

8. Фінагіна О. В. Ринкова трансформація в регіоні: особливості розвитку та діагностування: монографія. Донецьк: Юго-Восток, 2005. 228 с.

9. Шемякин Д. Малий та середній бізнес в Україні. URL: https://www.unian.ua/economics/finance/10596576-maliy-ta-seredniy-biznes-vukrajini-daye-55-vvp-kabmin.html.

10. Davidova S., Gorton M., Ratinger T., Zawalinska K., Iraizoz B. Farm productivity and profitability: a comparative analysis of selected new and existing EU member states. Comparative Economic Studies. 2005. Vol. 47. No. 4. Pp. 652-674. https://doi.org/10.1057/palgrave.ces.8100066

11. Ling L. S. Impacts of information technology capabilities on small and medium enterprises (SMEs) and Large Enterprises. Journal of Innovation Management in Small and Medium Enterprise. 2017. Vol. 2017. 133143. https://doi.org/10.5171/2017.133143.

12. Poufinas T., Galanos G., Papadimitriou P. The competitiveness of small and medium enterprises in adverse economic environments. Theoretical Economics Letters. 2018. Vol. 8. Pp. 2788-2802. https://doi.org/4236/tel.2018.813175.

13. Savickiene J., Miceikiene A. Sustainable economic development assessment model for family farms. Agricultural economics - Czech. 2018. Vol. 64. Pp. 527535. https://doi.org/10.17221/310/2017-AGRICECON.

14. Sousa S. D., Aspinwall E. M., Rodrigues A. G. Performance measures in English small and medium enterprises: survey results. Benchmarking: An International Journal. 2017. Vol. 13. No. (1/2). Pp. 120-134. https://doi.org/10.1108/14635770610644628.

15. Spicka J., Hlavsa T., Soukupova K., Stolbova M. Approaches to estimation the farm-level economic viability and sustainability in agriculture: A literature review. Agricultural economics - Czech. 2019. Vol.65. Pp. 289-297. https://doi.org/10.17221/269/2018-AGRICECON.

16. Ruchkina G., Melnichuk M., Frumina S., Mentel G. Small and medium enterprises in regional development and innovations. Journal of International 


\section{Agricultural and Resource Economics}

www.are-journal.com

Studies. 2017. Vol. 10. No.4. Pp. 259-271. https://doi.org/10.14254/20718330.2017/10-4/20.

17. Teletov O., Grigorenko V. The state and prospects of marketing strategiesforsmall and medium business enterprisesin Ukraine. Innovative technologies and scientific solutions for industries. 2019. Vol. 2. Pp. 97-104. https://doi.org/10.30837/2522- 9818.2019.8.097.

18. Jankelova N., Remenova K., Skorkova Z., Nemethova I. Innovative approaches to management with emphasis on soft factors and their impact on the efficiency of agribusiness companies. Agricultural economics - Czech. 2019. Vol. 65. Pp. 203-211. https://doi.org/10.17221/202/2018-AGRICECON.

19. Господарський кодекс України від 16.01.2003 p. № 436-IV. URL: http://zakon2.rada.gov.ua/laws/show/436-15.

20. Офіційний сайт Державної служби статистики України. Показники діяльності суб'єктів господарювання. URL: www.ukrstat.gov.ua.

21. Офіційний сайт групи Світового банку. URL: https://russian.doingbusiness.org/ru/rankings\#.

\section{References}

1. Apostolyuk, O. Yu. (2017), State financial policy to support the development of small business, Abstract of PhD dissertation, Money, finance and credit, Kyiv National University of Trade and Economics, Kyiv, Ukraine.

2. Derevyanko, A. (2019), Small Business Sentiment Index, available at: https://eba.com.ua/wp-content/uploads/2018/03/Indeks-nastroyiv-malogo-biznesu.

3. Efremova, O. S. (2018), Lending to small business in Ukraine. Ekonomka ta derzhava, vol. 7, pp. 82-85

4. Ivanytska, S. and Troyan, Yu. (2019), Prospects of Small and Medium Business Development in Ukraine. Modern Economics, vol. 18, pp. 49-54, available at: https://doi.org/10.31521/modecon.V18(2019)-08.

5. Mazur, K. V. and Simonik, L. S. (2018), State of the business environment of small and medium-sized enterprises in Ukraine. Molodyi vchenyi, vol. 5, no. 57, pp. 726-729.

6. Mostovyi, G. I., (2002), Ahrobiznes: derzhavne rehuliuvannia [Agribusiness: state regulation], Osnova, Kharkiv, Ukraine.

7. Sivitskaya, Yu. O. (2019), Estimation of agricultural enterprise for investment purposes: methodological aspect. Modern Economics, no. 15, pp. 175-182, available at: https://doi.org/10.31521/modecon.V15(2019)-25.

8. Finagina, O. V. (2005), Rynkova transformatsiia $v$ rehioni: osoblyvosti rozvytku ta diahnostuvannia [Market transformation in the region: features of development and diagnosis], Yuho-Vostok, Donetsk, Ukraine.

9. Shemyakin, D. (2019), Small and medium business in Ukraine, available at: https://www.unian.ua/economics/finance/10596576-maliy-ta-seredniy-biznes-vukrajini-daye-55-vvp-kabmin.html.

10. Davidova, S., Gorton, M., Ratinger, T., Zawalinska, K. and Iraizoz, B. 


\section{Agricultural and Resource Economics}

www.are-journal.com

(2005), Farm productivity and profitability: a comparative analysis of selected new and existing EU member states. Comparative Economic Studies, vol.47, no. 4, pp. 652-674. https://doi.org/10.1057/palgrave.ces.8100066.

11. Ling, L. S. (2017), Impacts of information technology capabilities on small and medium enterprises (SMEs) and Large Enterprises. Journal of Innovation Management in Small and Medium Enterprise, vol. 2017, 133143. https://doi.org/10.5171/2017.133143.

12. Poufinas, T., Galanos, G. and Papadimitriou, P. (2018), The competitiveness of small and medium enterprises in adverse economic environments. Theoretical Economics Letters, vol. 8, pp. 2788-2802. https://doi.org/4236/tel.2018.813175.

13. Savickiene, J. and Miceikiene, A. (2018), Sustainable economic development assessment model for family farms. Agricultural economics - Czech, vol. 64, pp. 527-535. https://doi.org/10.17221/310/2017-AGRICECON.

14. Sousa, S. D., Aspinwall, E. M. and Rodrigues, A. G. (2006), Performance measures in English small and medium enterprises: survey results. Benchmarking: An International Journal, vol. 13 no. (1/2), pp. 120-134. https://doi.org/10.1108/14635770610644628.

15. Spicka, J., Hlavsa, T., Soukupova, K. and Stolbova, M. (2019), Approaches to estimation the farm-level economic viability and sustainability in agriculture: A literature review. Agricultural economics - Czech, vol.65, pp. 289-297. https://doi.org/10.17221/269/2018-AGRICECON.

16. Ruchkina, G., Melnichuk, M., Frumina, S. and Mentel, G. (2017), Small and medium enterprises in regional development and innovations. Journal of International Studies, vol.10, no. 4, pp. 259-271. https://doi.org/10.14254/20718330.2017/10-4/20.

17. Teletov, O. and Grigorenko, V. (2019), The state and prospects of marketing strategiesforsmall and medium business enterprises in Ukraine. Innovative technologies and scientific solutions for industries, vol. 2, pp.97-104. https://doi.org/10.30837/2522- 9818.2019.8.097.

18. Jankelova, N., Remenova, K., Skorkova, Z. and Nemethova, I. (2019), Innovative approaches to management with emphasis on soft factors and their impact on the efficiency of agribusiness companies. Agricultural economics - Czech, vol. 65, pp. 203-211. https://doi.org/10.17221/202/2018-AGRICECON.

19. The Verkhovna Rada of Ukraine (2003), The Law of Ukraine «Economic Code of Ukraine», available at: http://zakon2.rada.gov.ua/laws/show/436-15.

20. The official site of the State Statistics Service of Ukraine (2019), Business entities' performance indicators, available at: www.ukrstat.gov.ua.

21. The official site of the World Bank Group, available at: https://russian.doingbusiness.org/ru/rankings\#. 


\section{Agricultural and Resource Economics}

www.are-journal.com

How to cite this article? Як цитувати цю статтю?

Стиль - ДСТУ:

Шевченко А., Петренко О. Сучасний стан розвитку мікро та малого агробізнесу в Україні. Agricultural and Resource Economics. 2020. Vol. 6. No. 1. Pp. 146-160. URL: http://are-journal.com.

Style - Harvard:

Shevchenko, A., Petrenko, O. (2020), Current state of micro and small agribusiness in Ukraine. Agricultural and Resource Economics, vol. 6, no. 1, pp. 146-160. URL: http://are-journal.com. 